\title{
SZÓNOKYNÉ ANCSIN GABRIELLA - PÁL VIKTOR - KARANCSI ZOLTÁN (SZERK.): A HATÁROK KUTATÓJA: TANULMÁNYKÖTET PÁL ÁGNES TISZTELETÉRE
}

\author{
(Magyarságkutató Tudományos Társaság, Szeged-Szabadka, \\ 2007, 283 o.)
}

\section{ERDÖSI FERENC}

Legyenek bár hölgyek, a tudomány müvelöi hiúságának mértéke nem életkorfüggő. Életkoruk némelykor azoknak tabu, akik az eltelt néhány évtizedükhöz képest kevés eredményt tudnak felmutatni. Pál Ágnes professzor asszony életművét leltározva viszont kevésnek tủnik a 65 év a tanári és kutatói pályájának tiszteletre méltó menynyiségủ és minöségủ, meggyőzően dokumentált sokféle eredményéhez képest.

Különleges és nem igazán kiforrott müfaj a születésnapi tiszteletkötet. Szerencsére nincsenek szabályai, ezért a szervező kollégán(-kon) múlik, hogy milyen szempontokat érvényesít(tenek) a szerzők kiválasztásakor és mekkora szabadságot enged(nek) a kötet egyes tanulmányai témájának megválasztásához. Ideális esetben a tanulmányok az ünnepelt kutatási profiljához igazodóak. Ebben az esetben a szerkesztőre vár a nehéz, ám szakmailag nagyra értékelhető feladat: a kötet végére a föbb gondolatokat csokorba szedő és összegező néhány oldalas fejezet megírása. Erre itt nem került sor.

Más, hasonló célból szerkesztettekhez képest ebben a kötetben - a 12 szerző által jegyzett köszöntésekkel és nem utolsósorban a remekbe szabott laudációnak sikerült két előszóval - jóval nagyobb hangsúlyt kapott az érzelmi elem. A kedves, egyéni hangvételü méltatásokat az ünnepelt iránti szeretet, a kialakult barátságok teszik hitelessé és egyben színes olvasmányélménnyé.

A kötet szakmai/tudományos tartalmát 26 (összesen 29 szerzőtöl származó) 6-14 oldal között váltakozó terjedelmủ tanulmány reprezentálja. Közülük kifejezetten határkutatási vonatkozású mindössze hat, míg további nyolc valamelyik (magyarok által is lakott) határon túli régió valamilyen speciális (de a határmentiséggel nem összefüggö) alágazati témájával, kettő Kárpát-medencén túli térség tematikusan idegen problémájával, hat Magyarország valamilyen országos különleges témájával, négy valamelyik magyar térség speciális problémájával foglalkozik.

A tanulmányok hatékonyabb szakmai értékesülése érdekében az „áldemokratikus” szerzői névsorba szedés helyett a szerkesztőnek témacsoportok, valamint területkategóriák (egész Magyarország, vagy magyar és külföldi térségek település- és népességföldrajza, valamint funkcionális problémái) szerint kellett volna csokorba 
szedni a kéziratokat. Erre már csak a kötetben közölt tematikailag rendkívül heterogén ismeretanyag könnyebb áttekinthetősége érdekében is szükség lett volna. A formalitásnak tett szerkesztői engedmény következtében a tanulmányokat sorban olvasó kapkodja a fejét, amikor a magánüdülök magyarországi helyzetképe után a vajdasági magyarok regionális tudatáról szóló fejezetre, vagy az Ems völgyének sajátos településhálózatáról a posztkommunista országok beli turizmust ismertetö írásokra siklik át a tekintete.

Könyvészetileg - az izléses és szellemes borító, a gazdag tipográfia és ábraszerkesztés által látványosan bizonyítottan - a kötet igényes munka, dicséri a technikai szerkesztőt, Pál Viktort.

A 283 oldalas kötet megjelentetése példaértékủ összefogás eredménye - szegedi, pécsi, sőt szabadkai résztvevőkkel. A határ mindkét oldalának aktorai közös ügynek tekintették a könyv megjelentetését.

A recenzens meggyőződése, hogy országhatáraink átjárhatóságának fokozatos javulása nem változtat a határ menti térségek kutatásának fontosságán, mert az új folyamatok (lásd az ingázás irányának megfordulását a román-magyar határon) bőven kínálnak izgalmas kutatási témákat. 